Teresa Garulo es Catedrática en la Universidad Complutense de Madrid, donde enseña lengua árabe y su literatura desde hace casi cinco décadas. En esas varias vidas de entrega a la docencia y la investigación universitarias, la traducción ha sido siempre su piedra angular, actuando no solo como instrumento para el conocimiento del otro y su cultura, sino como meta cifrada en el placer de dar verso por verso y literatura por literatura. El contenido de esta entrevista se mueve en tres espacios relacionados: sus años de formación como filóloga y arabista; su dedicación al estudio y traducción de la poesía andalusí, con evidente predilección por las grandes voces femeninas; y su actividad como traductora profesional para editoriales comerciales.

PALABRAS ClaVE: Teresa Garulo, arabismo, traducción, poesía andalusí, García Gómez, Ediciones Hiperión.

\title{
Teresa Garulo,
}

\section{traductora de poesía} andalusí

\author{
Luis Miguel Pérez Cañada \\ Escuela de Traductores de Toledo (UCLM)
}

\section{Interview with Professor Teresa Garulo, translator of Andalusian poetry}

Teresa Garulo is Professor at Complutense University in Madrid, where she has been teaching Arabic language and Arabic literature for almost five decades. Teaching, research and translations have been the cornerstone of her career. According to her experience, translation is an instrument for the knowledge of the Other and its culture, as much as an aesthetic goal. The content of this interview moves between three spaces interconnected: her formative years as a philologist and orientalist; her five decades of work dedicated the study and translation of Andalusian poetry, especially her female voices; and her work as a professional translator for commercial publishers.

KEY WORDS: Teresa Garulo, orientalism, translation, Andalusian poetry, García Gómez, Ediciones Hiperión. 


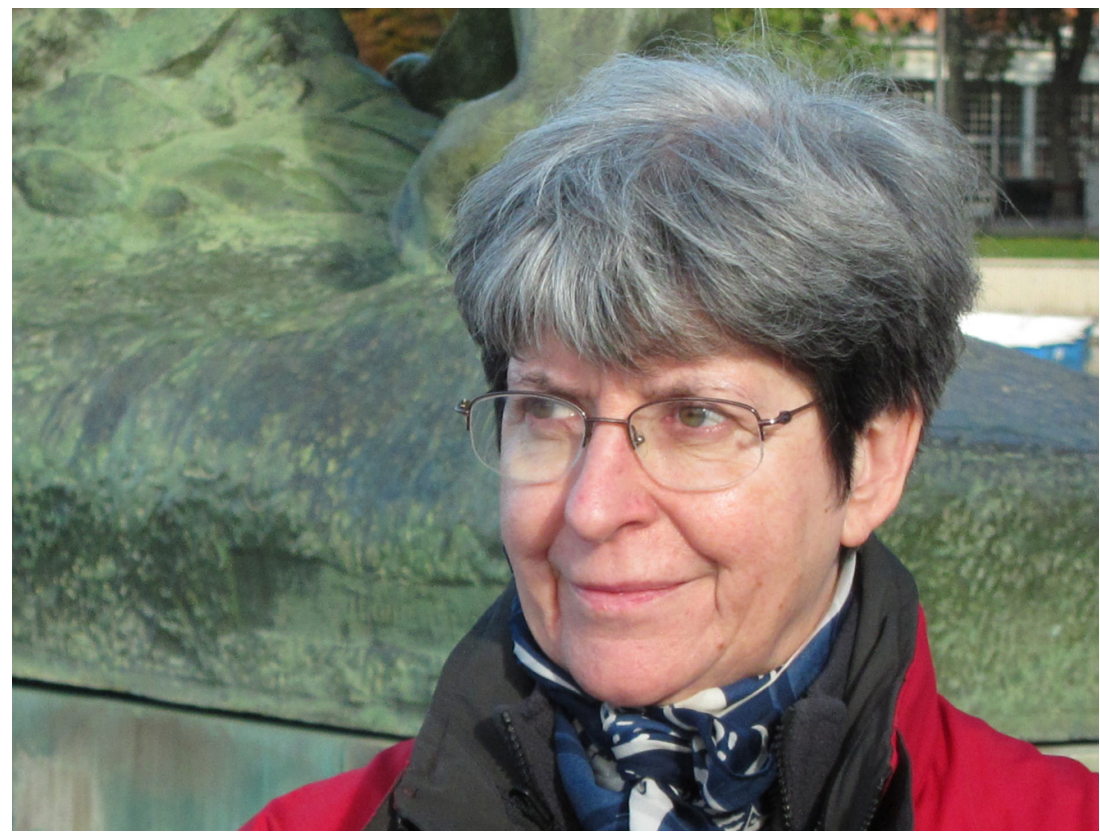

Teresa Garulo

Teresa Garulo (San Martín de la Vega, Madrid, 1950) es Catedrática en la Universidad Complutense de Madrid, donde enseña lengua árabe y su literatura desde hace casi cinco décadas. En esas varias vidas de entrega a la docencia y la investigación universitarias, la traducción ha sido siempre su piedra angular, actuando no solo como instrumento para el conocimiento del otro y su cultura, sino como meta cifrada en el placer de dar verso por verso y literatura por literatura. Cinco décadas consagradas a traducir y difundir la mejor poesía árabe y de al-Ándalus, con una evidente predilección por las grandes voces femeninas. El contenido de esta entrevista ${ }^{\mathrm{I}}$ se mueve por tanto, inevitablemente, entre sus años de formación como filó-

Entrevista realizada el 27 de mayo de 2019 en la Escuela de Traductores de Toledo. loga y arabista -en la línea de las entrevistas recogidas en la obra Arabismo y traducción-, ${ }^{2}$ por un lado, y su producción como traductora para editoriales comerciales especializadas en poesía, léase Ediciones Hiperión, por otro. Antes de encender la grabadora, hablamos de las memorias de infancia de Miguel Sáenz en Sidi Ifni, del homenaje a Antonio Lozano en Casa Árabe unos días atrás y de otros paisanos, nacidos o vinculados fuertemente a Marruecos, como Javier Valenzuela, Malika Embarek, Antonio Peral. Estábamos comentando las traducciones de Rafael Cansinos Assens, su marcado orientalismo...

2 Véase Arias Torres, Juan Pablo; Manuel C. Feria García y Salvador Peña Martín : Arabismo y traducción. Entrevistas con J. M. Fórneas. J. Cortés, M. Cruz Hernández, J. Vernet, L. Martinez, P. Martinez, M. L. Serrano, Madrid: CSIC, 2003 . 
[...] A mí me parece que eso es exótico. Es más, yo creo que esa traducción está hecha del alemán, por más que digan.

¿Te refieres a Las mily una noches, la de Aguilar?

Sí. Las transcripciones están todas tomadas del alemán. Y disfrazarlo de más orientalista, cogiendo cosas de aquí y de allí, me parece que es una forma de tergiversar la realidad.

La idea de que en esa versión se traslucen calcos de otras lenguas creo habérsela leído a José María Fórneas o a Juan Vernet. ${ }^{3}$

Estoy convencida de que es así. Cuando Cansinos traduce en los años ' 30 o ' 40 del siglo pasado, hay un gusto muy acentuado por el orientalismo. Pero es para que parezca más auténtico. Es como si pensásemos que almalaques es un arabismo. Pues no, no lo es. Nadie dice almalaques con el significado «ángeles». Lo hacen los moriscos, que quieren mantener sus palabras porque son las del Corán. Y lo mismo ocurre con los traductores de la mezquita de la M-3o en Madrid y su traducción del Corán, que además ni siquiera ponen la lectura que han escogido, o a qué ulemas han seguido. Eso me parece poco serio. Sobre todo con cosas tan tremendas como es el Corán. Tan tremendas en el sentido de que te expones a una herejía.

Empecemos por el principio, si te parece bien. Eres filóloga de carrera, como casi todos los traductores e intérpretes formados antes de que se crearan en España las Facultades de Traducción. ¿̇Podrías hablarnos de aquellos años de formación y en concreto del lugar que la traducción ocupaba en ella?

Cuando hacíamos Filosofía y Letras y nos especializábamos en alguna lengua un poco diferente, como latín y griego, la versión-

3 Ibídem, p. 58. traducción era inherente al oficio, a la carrera. No se tenía tanto miedo a la traducción. Hoy parece que decir gramática-traducción es hablar de un mal método para aprender una lengua, pero depende de para qué quieres esa lengua. Traducir es el paso necesario para entender algo expresado en una lengua extranjera. Ahora tengo que convencer a los alumnos en clase de que eso, en realidad, no es traducción; es comprensión de un texto. Ahora bien, escribir lo que uno entiende de un texto todo seguido en español racional no es tan fácil... Antes de que existieran las Facultades de Traducción, muchísima gente que no había hecho filología había traducido. Si piensas por ejemplo en el siglo XVIII, Iriarte sabía inglés y por supuesto francés, y traducía. No era necesario que fueran filólogos. Sabían lenguas, aunque a veces se pusieran despectivos, como Cervantes, con las traducciones del italiano.

De esos años de formación, ¿̇hay algún dato biográfico que quieras señalar por parecerte determinante para tu actividad traductora posterior?

Quería estudiar una lengua clásica. Lo que pasa es que en mi familia se pensaba que el árabe también era una lengua clásica. Era una opción más o menos remota, pero justo el verano antes de entrar en la universidad hice una excursión a El Escorial. En la biblioteca había una exposición de manuscritos árabes, y allí delante me dije: «Esto es lo que quiero». Luego no he trabajado apenas con manuscritos, pero vi aquellos y me maravillaron. Mi padre al principio dijo que muy bien, que para ser historiador medievalista había que saber árabe. Lo que pasa es que a mí la historia no me interesaba. Supongo que luego me pasó como a tantas personas que hicieron árabe en los tiempos en que teníamos «comunes». Descubrían el árabe y se quedaban fascinados por la lengua. En mi caso, 
estaba dispuesta a dejarme seducir por el árabe. Tuve de primera profesora a Rafaela Castrillo. ${ }^{4}$

\section{4}

\section{Hablas del último tercio de los años 6o, ¿̇erdad?}

Sí, del curso i967-ı968. Ese año llegó la avalancha del baby boom de los años 50. Aquel curso, en primero de "comunes» había seis grupos, con unos 300 alumnos por grupo. En una clase con tanta gente no te puedes plantear más que aprender gramática y traducir textos. Lógicamente, traducíamos cuentos de la Crestomatía de Asín. 5 Y aprendíamos muchísima gramática. Nos defendíamos bastante bien. Además, Rafaela Castrillo nos ofrecía empezar la clase media hora antes, a los que quisiéramos, y nos daba «Historia». Ahí te enterabas de los primeros tiempos del islam. Así es que a ella le tengo un especial cariño. Entonces pensé que no me daba demasiada buena nota, porque me daba sobresaliente. Bueno, es que... era la asignatura que yo trabajaba más. En segundo ya no la tuve a ella. Pasamos a la Antología de García Gómez, ${ }^{6}$ que a mí sigue pareciéndome una antología de cuentos maravillosa. Y la pongo sin ninguna reserva en los primeros cursos. Porque son cuentos fáciles, que enseñan mucho de la religiosidad popular; hay también cuentos divertidos, pero con los chistes se encuentran dificultades derivadas de que el humor con frecuencia no se deja entender bien fuera del contexto cultural. Hay textos algo más difíciles; me encanta el fragmento de Nafh at-tib, de la descripción de Medina Azahara, y el de Yusuf

\footnotetext{
4 Viguera Molins, María Jesús: «En homenaje a la profesora Rafaela Castrillo Márquez», Anaquel de Estudios Arabes, 2003, I4, pp. 309-3I2.

5 Asín Palacios, Miguel: Crestomatía del árabe literal con glosario y elementos de gramática, Madrid: Instituto Arias Montano, I942.

6 García Gómez, Emilio: Antología Arabe para principiantes. Textos árabes sin vocalizar seleccionados y reeditados con un glosario, Madrid: Espasa-Calpe, I944.
}

y Zulaija, aunque me parece un cuento un poco atrevido. Creo que están muy bien escogidos, porque son de un nivel medio, con un vocabulario muy frecuente. Mientras que en la Crestomatía de Asín muchos de los textos son bastante difíciles. La ventaja fundamental de ambas son los glosarios. Al principio es muy difícil manejar bien un diccionario que merezca la pena, porque ofrecen demasiadas acepciones, demasiadas raíces, demasiadas posibilidades. La de Asín estaba planteada para un curso de doctorado, para gente que no había estudiado árabe y decidía especializarse en filosofía, o historia o mística. En ella encuentras textos de Ibn Jaldún o de Averroes. También hay cuentecitos, y algunos estupendos, como el encuentro de al-Ramadi con Jalua (de El collar de la paloma), cuentos de amor romántico...

Creo que acabas de apuntar la razón de ser de las traducciones del árabe durante casi tres cuartos del siglo XX. $\dot{\zeta} T$ e parece que eran un instrumento para fundamentar una concepción bistórica, filosófica $y$ literaria particulares?

El programa de lecturas de la Crestomatía de Asín es muy interesante para una persona que no ha tenido cinco años de estudios de árabe, que le interesan temas medievales, filosofía e historia, que necesita quemar etapas muy deprisa; por eso son textos vocalizados, y van acompañados de unos elementos de gramática bastante claros. Están autores con los que Asín trabajaba habitualmente, como Ibn Hazm o Algazel. Es un método pensado para lo que está pensado. En ese sentido me parece modélico. Quizá no es lo que ahora necesitamos. Pero eso es otra historia. Y en el caso de la Antología de García Gómez, ya sin vocales, es fruto de la busca de textos normales, sin grandes dificultades. Sí, incluye un capítulo de El collar de la paloma, que es el más difícil porque es prosa rimada - sí, a veces no somos del todo 
conscientes de ello- Es dificil porque es ensayo y el ensayo medieval es muy difícil. Le pasa a alYáhiz, le pasa a al-Tawhidi..., de los que yo he leído.

\section{Le pasa a Ibn al-Muqaffa...}

Sobre Ibn al-Muqaffa, recuerdo que en tercero tuve de profesor a Salah Fadl, un profesor absolutamente extraordinario, muy serio, a diferencia de otros profesores árabes que llevaban un ritmo más relajado... Él decía que había que empezar con Ibn al-Muqaffa y al-Yáhiz. Con Ibn al-Muqaffa yo me lo creí. Y cuando comencé a dar clases pensé usarlo, pero enseguida, tras un breve intento, me dije «Dios mío, esto no se puede poner en comunes». Incluso para mí era demasiado complicado. Ese primer año de profesora tuve de alumno a Vicente Fernández, que quizás está detrás de esta conversación. Era un curso del turno de tarde, que yo había intercambiado con Fernando de Ágreda. En este mundo actual, en que muchos de nuestros alumnos tienen que trabajar para costearse los estudios y ganarse la vida, echo bastante de menos la posibilidad de turnos de mañana y de tarde. Entonces teníamos clases mañana, tarde y noche. Cuando empecé a trabajar en la facultad había 3I grupos de árabe: 15 de primer curso y 16 de segundo, o viceversa.

Hay profesores que fijan vocaciones sin pretenderlo. ¿DDirias que existía entonces una persona, una escuela o un método de los que hoy te sientes discípula o continuadora, como arabista y traductora? Además de a los profesores Castrillo y Fadl, ¿̇a quién recuerdas especialmente?

Mis profesores de referencia, en cuanto a escuela arabista y filológica, son don Emilio García Gómez - fui alumna suya durante tres años-, don Elías Terés en literatura, y don Fernando de la Granja, de quien me he considerado siempre discípula, tanto en investigación, como en su aproximación a los textos árabes. Pero antes de entrar en la especialidad, hubo un profesor que influyó sobre todo en la orientación práctica de mi carrera, y en la elección de la poesía como objeto de estudio académico: Andrés Amorós, mi profesor de Literatura española en segundo de «comunes». Como mis padres eran profesores - Historia, Lengua y literatura españolas-, la biblioteca de casa reflejaba sus intereses. Todos leíamos poesía desde muy pequeños. También en la escuela entonces se aprendían poemas, y luego, en los primeros años de bachillerato, incluso algo de métrica. Fue importantísimo el momento en que llegaron a casa todos los volúmenes editados hasta la fecha de la Biblioteca Clásica Ebro (Zaragoza), cuando yo tenía ocho años. Y desde entonces el teatro clásico español fue una de las lecturas constantes de todos nosotros. Seguíamos leyendo poesía. Por eso, a mi hermana mayor y a mí nos llenaba de asombro que nos dijeran, cuando llegamos a la facultad, que el teatro clásico no se entendía. ¡Cómo que no se entiende, si yo llevo leyéndolo toda la vida y lo entiendo! Quiero decir que el gusto por la poesía, por la literatura clásica española, lo hemos mamado en la leche materna. Mis hermanos han sido grandes lectores de poesía, y descubridores de poetas nuevos, que yo no conocía, más ensimismada en los clásicos. Pero, como decía, Andrés Amorós influyó decisivamente en que lo que era una lectura para mi propio disfrute se convirtiese en una vocación académica. De dos maneras: por un lado, cambió la estructura del curso, y de leer el Quijote - no habría sido un problema para mí, porque en casa era una de las lecturas habituales, cuando nos reuníamos y mi padre leía mientras las demás hacían labores-, pasamos a leer seis obras de autores desde el Arcipreste de Hita al siglo Xx. Y para la poesía del siglo 
XX organizó un curso de comentario de textos de la Generación del 27, que nos daba Marina Mayoral, un día o dos a la semana, por la tarde. Mi formación en poesía había sido siempre muy clásica, y de la Generación del 27 apenas conocía más que a Lorca —otro de los autores favoritos de mi madre- En el taller de comentario de textos que organizó Marina Mayoral vimos muchísimos poemas de la Generación del 27. Entonces descubrí que la poesía no era solo para disfrutarla, sino que se podía estudiar, que se podría trabajar sobre ella. Cuando entré en la especialidad ya sabía que quería especializarme en poesía árabe. Lo de ser historiadora lo había descartado antes porque sabía que mi interés por la historia era un poco anecdótico, conocer enlaces matrimoniales, fechas, batallas... un poco frívolo, podría decirse. En aquella época se llevaba estudiar el precio del trigo, la economía como motor de la historia. Andrés Amorós también comentó en clase algo que me impactó mucho. Yo quería hacer Semíticas, porque había escogido dedicarme a al-Ándalus. Sabía, porque me lo decían mis padres, que con árabe iba a tener salida en la investigación o en la universidad. Amorós comentó que había que hacer la tesina cuanto antes, que sin ella no se podía trabajar en la universidad. Además, también puntuaba para oposiciones de instituto. Por eso me dije «voy a empezar con la tesina en cuanto entre en tercero». Tuve un momento difícil cuando me matriculé en tercero, porque a mis padres les pareció que no iba a tener trabajo en toda mi vida, que me moriría de hambre. Eso tuvo de ventaja que trabajé como loca. Durante esos años hice también la tesina, 7 que presenté al acabar quinto. Como había déficit de profesores de árabe, me contrataron para el curso siguiente.

7 Garulo, Teresa: «Poemas de Al-Rusafi». Tesis de licenciatura dirigida por Fernando de la Granja. Universidad Complutense de Madrid, I972 (inédita).
Dos años después, cuando Filosofía y Letras se dividió en tres Facultades: Filosofía, Historia y Filología, los cursos se redujeron drásticamente, y me contrataron de Profesor Ayudante.

\section{¿Cuántos estudiabais en la especialidad?}

En ese año de tercero los matriculados de árabe éramos cinco: Mercedes García-Arenal, Esmeralda de Luis, que ha estado en el Instituto Cervantes, o equivalente, Leonor Carracedo, que se pasó a hebreo, y un chico que me parecía mayorcísimo, era 22 años mayor que yo, que se llamaba Julián Peréz Rocamora, que sabía chino y debía de ser funcionario, no sé en qué departamento de la Administración, a quien le encantaban las lenguas. Y acabamos los cinco. En clase de hebreo se incorporaban estudiantes de generaciones anteriores, porque teníamos a Cantera, que era durísimo. A mí sin embargo me caía bien, y me dio matrícula. Teníamos un plan de estudios que sigo recordando como estupendo, con muchas optativas, pero que muchísimas. Ahora pienso que tanta «optatividad» podía ser un problema para los profesores. Para los estudiantes, no, porque podías hacer lo que quisieras. Me matriculé en asignaturas de lengua y literatura árabes, pero me convencieron de que me matriculara por lo menos en una asignatura de historia. Lo hice y tuve a [Pedro] Chalmeta. Siguió sin interesarme la historia. Todas las demás asignaturas en que me matriculé fueron de lenguas. El plan tenía árabe y hebreo los tres años. Arameo en cuarto. Había una asignatura de "Prácticas de árabe», por cada curso de árabe, también optativas; en planes posteriores, las asignaturas de «Prácticas» se eliminaron. Pero permitía cursar el doble de asignaturas de lengua árabe que ahora. También las había de «Prácticas de hebreo».

¿Qué haciais en la asignatura de "Prácticas»? 
Seguir leyendo y seguir traduciendo. Tuve en «Prácticas de árabe» en ese tercer año también a Rafaela Castrillo y me pareció estupendo. Sobre todo, porque nos puso bastantes canciones, otra forma de ver poesía, esta vez moderna. Trabajábamos mucho y se aprendía mucho. Usamos también el libro de Zyadeh, que tenía cintas de magnetofón; tengo algunas, pero no recuerdo el título exacto del método. ${ }^{8}$ Enfocada específicamente para hablar estaba otra asignatura, «Árabe hablado». En la de «Prácticas de árabe» de quinto curso, veíamos prensa y aprendíamos a redactar noticias en árabe. Trabajábamos bastante. «Literatura árabe» $\mathrm{y}$ «Literatura hispanoárabe» las daba don Elías Terés. Ahí aprendías a apreciar la poesía árabe clásica, porque le ponía tal pasión... Copiaba el texto árabe en la pizarra o lo repartía en papeles que se hacían con ciclostil, aprendíamos a medir, y cualquier traducción que te diese en clase era estupenda. Veíamos fragmentos de sus versiones de las mu'allaqat $y$ te encantaban. Eso no me ha pasado luego con otras lecturas de poemas preislámicos. Con él los vivías. Te fascinaban sus versiones de Shanfara: «[...] y me voy como llegué, cuando la noche es más noche». En tercero tenía una hora libre entre dos clases y entré en la clase de «Prácticas de árabe» de cuarto, con Salah Fadl, sin estar matriculada. Hice todas las asignaturas de lengua que pude. En quinto cogí «Acadio» y también disfruté con lo que se estudiaba... Había cinco asignaturas por curso, menos en cuarto que eran seis. Se podía trabajar muy a gusto. Salah Fadl me pareció un profesor maravilloso. Incluso hacíamos traducción inversa: durante varias semanas traducíamos de español a árabe $E l$ sombrero de tres picos. Tradujimos sobre todo textos de autores orientales, y tam-

\footnotetext{
8 Zyadeh, Farhat J. y R. Bayly Winder: An Introduction to Modern Arabic. Princeton, New Jersey: Princeton University, 1957 .
}

bién bastantes poemas arabigoandaluces. En esa época había personas que insistían mucho en que García Gómez se inventaba las traducciones. Entonces Salah Fadl quiso probarlo, verlo. Tradujimos varios poemas de Qasidas de Andalucía, y comentó: "iAnda, pues en ésta - la casida en nun de Ibn Zaydun- sólo hay una expresión que no coincide (con el árabe)». No se estaba inventando, estaba traduciendo, empleando palabras quizás suyas. Además, quien no se haya equivocado jamás en árabe en una traducción que tire la primera piedra. Todos hemos metido la pata. Pero él no estaba falseando nada. Con algunas traducciones no estoy de acuerdo.

García Gómez, ya cumplidos los setenta, se enorgullecia de haber transmitido su saber a un grupo numeroso y brillante de arabistas diseminados por toda España, ${ }^{9}$ y son muchos los que han ensalzado su magisterio.

A mí me pareció un profesor muy bueno. Se incorporó un par de meses después de empezar el curso, y Rafaela Castrillo nos anunció su llegada diciéndonos en clase: «Ahora llega García Gómez, que va a darles clase a ustedes. Es un especialista en poesía andalusí. Pídanle que les ponga a traducir poemas arabigoandaluces». Estaba yo en tercero, o sea, en primero de especialidad. Lo primero que nos preguntó es «¿Qué querrían ustedes ver?» Y dije poesía hispanoárabe. No sé si hizo caso en ese momento, pero lo hizo más adelante y el pobre debió de acabar desalentado. No me puedo olvidar un poema describiendo un caballo. Te salía la palabra tirf «caballo de raza» que podía ser tarf «ojos», y

9 García Gómez, Emilio: «Discurso de investidura con el grado de Doctor honoris causa por la Universidad de Granada». En Elegia Andaluza. (Homenaje a D. Emilio García Gómez). Sevilla: Asociación Andaluza de Profesores de Español Elio Antonio de Nebrija, 1997, p. I3o. 
tú además sabías taraf «extremo». Debían de salirnos unas cosas espeluznantes. Y al cabo de poco tiempo decidió que mejor sería traducir a Tawfiq al-Hakim. Fue una elección estupenda, porque - explicó- «hay estas obras cortitas de teatro de un solo acto. Son diálogos que sirven para practicar si quieren estudiárselos. Además es un árabe de no demasiada dificultad...». Y desde entonces tengo pasión por Tawfiq al-Hakim. Fue el primero en que me solté, podía leerlo en el metro, en el tren de Cercanías cuando vivía en Móstoles, sin diccionario. Antes iba siempre cargada de diccionarios. Luego tradujimos muchísimas más cosas. Estuvimos traduciendo textos geográficos —al-Udri, recién editado en el Instituto Egipcio-, porque decía que eran fáciles. Efectivamente lo eran. El último año tradujimos prólogos de Ibn al-Jatib. Nos decía - creo que con toda la razón- que la poesía es bastante fácil de traducir, porque el metro y las convenciones poéticas te guían. Mientras que en prosa rimada no sabes por dónde va a salir el autor.

\section{¿Cómo era él en clase?}

A mí me parecía fascinante. Ponía mucha pasión en las clases; y a veces contaba anécdotas de sus años en Iraq, Irán y Turquía -insistía mucho en que había que estudiar persa y turcoque explicaban de forma muy sugerente cómo era ese mundo al que intentábamos asomarnos. O hablaba de sus maestros, Asín y Ribera. A él le pasaba como a Ribera: no creía en los exámenes. Nunca nos examinó de árabe, examinaba a los que le parecía que suspenderían. Entonces los derivaba, se los mandaba a que les pusiera Granja un examen. A Granja lo tuve en cuarto en «Textos literarios árabes», una asignatura que hemos mantenido muchos años en el plan de estudios. Recuerdo que muy pocos la escogían - era a primera hora de la mañana - y que por una u otra razón yo asistía casi siempre sola a sus clases. Leíamos normalmente tres capítulos de cada novela, para ver vocabulario y estilos diferentes: de Mahfuz, Jalil Yubran, Abdel Quddus, Abdelhamid Abdallah, Mahmud Taymur... Cuando presenté la tesis, Granja estaba en el tribunal y comentó que ese curso habíamos traducido 200 páginas. Claro, estaba yo sola. Y a mí traducir me apasionaba. Aunque eso nos pasaba a todos, pensábamos que estábamos allí para traducir. Como Profesora Ayudante coincidí con Marcelino Villegas, que se pasaba todo el día traduciendo montañas de cuentos.

Quizás los Cuentos ciertos e inciertos de Mahfuz, que tradujo con María Jesús Viguera. ${ }^{\text {Io }}$

Probablemente, porque entonces Marcelino Villegas colaboraba mucho con María Jesús Viguera. Hacía ya tres o cuatro años que habían publicado Narraciones árabes del siglo $X X,{ }^{\text {II }} \mathrm{y}$ seguían con Zakariyya Tamer, y otros autores. También existía aquel proyecto maravilloso de los cuadernillos rojos y verdes de la Casa Hispano-Árabe. Ella y Marcelino acababan de terminar la carrera y ya estaban traduciendo y publicando en esos cuadernos. Todos pensábamos que parte de nuestro trabajo para la tesis doctoral o la tesina tenía que ser una traducción que mostrase, primero, que sabíamos; y segundo, que se podía publicar lo que traducíamos. María Jesús trabajaba entonces en la Autónoma. Yo la había conocido antes, en la Escuela de Estudios Árabes (Instituto Miguel Asín), cuando todavía estaba su sede en la casa de Asín. Después, la Escuela se trasladó a Hortaleza I04, donde hice la tesis. María Jesús era la bibliotecaria de la

Io Mahfuz, Naguib: Cuentos ciertos e inciertos. Traducción de Marcelino Villegas y María Jesús Viguera. Madrid: Instituto Hispano-Árabe de Cultura, I974.

II Narraciones árabes del siglo XX. Selección, traducción, presentación y notas de María Jesús Viguera y Marcelino Villegas, Madrid: Emesa, i969. 
Escuela, y me pidió que le llevase la carta de presentación de un profesor, para poder ir allí. Se la pedí a don Elías Terés. Y don Elías me dijo: «Qué tontería! ¿Cómo me voy a escribir una carta a mí mismo?». María Jesús y yo nos hicimos amigas y hemos sido amigas toda la vida. En algunos casos, incluso la ayudé un poco a pasar a máquina algún trozo de la tesis, cuando iba muy volada de tiempo; con ella aprendí a hacer bibliografías. Cuando terminé la carrera éramos muy muy amigas, de ir a comer a casa de sus padres todos los domingos.

Volviendo a García Gómez, es sabido que los Poemas arabigoandaluces, $y$ en general el Libro de las banderas de los campeones, son la partitura sobre la que trabajó toda su vida, probando técnicas diversas hasta quedarse con el endecasílabo como solución. ¿ Te puedo preguntar qué opinión te merecen esas versiones en endecasílabo?

Me gustan mucho porque, efectivamente, pienso que es el verso que, como dice él, «tiene más calor humano». Eso me parece que es verdad. Y además permite combinaciones de versos de sílabas impares. La silva de toda la vida, de II y 7 , que puedes organizar como quieras. Incluso 5 y 7, 9 y II, es un ritmo que funciona bien en español. De todas formas, Casidas de Andalucía es de I940, casi al principio de su carrera.

Hay otro García Gómez traductor de poesía, el de Todo Ben Quzman, el que somete la versión al ritmo del original.

Ahí el problema es más grave. Su traducción de las moaxajas, las de las jarchas romances de la serie árabe en su marco, me gusta. Y en algunos casos, el resultado me parece magistral. En Ben Quzman, no. Aunque también es posible que se deba a mi gusto por el árabe clásico frente al dialectal, no disfruto tanto con esos poemas.
Te pregunto más en relación con la traducción...

También me gusta menos, porque parece dura, difícil, exige condensar demasiado y forzar el orden natural del español. Hay una parte de su teoría métrica - métrica española- con la que no estoy de acuerdo, pues parece dar por sentado que, en métrica española, un poema tiene que tener todos los versos del mismo tipo desde el punto de vista de los acentos, es decir, todos los versos del poema tienen que tener, bien un ritmo acentual ternario (anapéstico / dactílico), o bien un ritmo binario (yámbico / trocaico), o una mezcla de ambos que denomina «ritmos anómalos». ${ }^{22}$ Pero, en mi opinión, eso no es así. En poesía española, en un poema conviven versos de distintos ritmos acentuales. El único acento obligatorio es el de la penúltima sílaba. Parece que la necesidad de que todos los versos de un poema tengan los acentos en las mismas posiciones es un invento bastante tardío, quizá finales del XVIII, y ya en el siglo XIX, con románticos (Bécquer — «Del salón en el ángulo oscuro»-, Carolina Coronado, Gertrudis Gómez de Avellaneda) y modernistas. Todos conocemos la «Sonatina» de Rubén Darío: alejandrinos claramente divididos en dos hemistiquios de siete sílabas con los acentos en 3 y 6. En árabe clásico el acento no cuenta métricamente, porque es fluctuante dentro de la misma palabra según su contexto. Y los acentos de la métrica española se pueden traspasar fácilmente a cualquier verso árabe, y la variedad rítmica no produciría ningún problema. Empeñarse en una rigidez que no tienen ni el español ni el árabe, usar siempre el mismo modelo acentual en todos los versos de un poema, obliga a forzar demasiado el ritmo, y eso me parece que

I2 García Gómez, Emilio: Métrica de la moaxaja y métrica española. Ensayo de medición completa del «Ğaiš altawš̌n de Ibn al-Hațīb, Madrid: Al-Andalus, I975, pp. I2-I3. 
hace el poema más pesado. $Y$ también exige prescindir de demasiadas cosas que dice el poema, porque el árabe es una lengua sintética y el español no. La ventaja del «calco rítmico» es que se ve mejor la forma del poema. En las moaxajas que he traducido, las de Ben Sahl, la forma se ha perdido casi por completo, es decir, el número de sílabas y las rimas no se ven. Pero, en general, suelo preferir decir todo lo que dice el texto en árabe.

¿Dirías que ésas son las mayores dificultades a la hora de traducir poesía andalusí, por encima de las de indole cultural, la polisemia, etc.?

Esas son las dificultades de la prosodia, o cómo traducir de una prosodia a otra, sin forzar las cosas. Más que la polisemia — ahí siempre se pierde alguna de las posibilidades-, siento más perder muchas connotaciones de las palabras. Cuando piensas en la cantidad de verbos que expresan, como sin darse cuenta, matices de luminosidad o de color, se siente bastante frustración. No es lo mismo decir asbaha que decir amsa o adba, y se emplean mecánicamente en el lenguaje cotidiano, pero en poesía tiñen de color lo que se dice, y los poetas son conscientes de ello: la luz blanca de la mañana, la oscuridad que va cayendo por la tarde, el brillo de media mañana. El adjetivo bid, con el que se juega para describir a las mujeres hermosas, blancas, o a las espadas brillantes. El color algo oscuro que evoca la palabra zaby "gacela», aplicada a jóvenes, etc. No se puede llenar todo de adjetivos. Y notas que vas perdiendo imágenes, percepciones de color. Al lado de éstas, están las derivadas de la propia dificultad del árabe. A veces, el verso es muy oscuro, y no lo entiendes. Eso creo que nos ha pasado a todos en algún momento. $\mathrm{O}$ quieres que diga algo en concreto; te haces una idea de lo que tiene que decir, y te empeñas en que lo diga, en lugar de buscar en otra dirección. Y menos mal si luego recapacitas y dices: «Pero, ¡si esto era mucho más simple y no me había dado cuenta!». Creo que también pasa en árabe moderno, en las novelas, que un día una frase se te atasca...

Si te sale un alejandrino o un endecasílabo espontáneamente, ¿̇lo conservas?

Por supuesto. Si me sale un alejandrino, un endecasílabo, o lo que sea; en primer lugar, me pongo muy contenta. $\mathrm{Y}$ a continuación lo arropo, lo mimo. El primero en hacerme una observación a este respecto fue Granja. Cuando le enseñé el libro de al-Rusafi, me dijo: «Mire... a este verso, si le cambia el orden de las palabras — sujeto y verbo-, le salen bien los acentos de un endecasílabo en español». Lo cambié en la segunda edición.

\section{¿Alguna vez has intentado adaptarte al metro de un poema?}

Sí, claro... con resultado incierto... Durante los años de vigencia del plan de estudios del 93 (1995-2009), en mi clase de doctorado sobre moaxajas, el último día lo dedicábamos a una especie de taller de traducción, ajustándonos al número de sílabas de alguno de los poemas traducidos ese año. Había alumnos que 10 hacían francamente bien, y era bastante divertido. Con la poesía, las dificultades son otras. Todo el mundo es capaz de decir en cualquier momento que la poesía es intraducible. Porque es verdad que no se puede traducir. Pero tampoco es exactamente cierto. Porque si sabes otra lengua y te gusta la poesía, quieres traducir los poemas de esa lengua y traduces. Les pasa a los que traducen del francés, a los del inglés, a todos los traductores. En parte es intraducible: no vas a poder trasladar el ritmo. Y luego está la experiencia personal frente a la poesía, y cada uno habla desde su punto de vista. Por ejemplo, a mí me han dicho chicas árabes que el original 
árabe era mucho más bonito que mi traducción, que yo pienso que estaba muy bien. Y creo que es porque el español no les dice tanto, como lengua aprendida tardíamente, mientras que el árabe - aunque a veces no lo entiendan- les sugiere algo más que lo que se cuenta, por todas las connotaciones que tienen las palabras.

$Y$ considerando que para los árabes la poesía - al menos hasta finales del siglo XX-es la creación más importante y más original de su cultura desde los tiempos preislámicos, ¿no te llama la atención lo tarde que es traducida en Europa?, donde hay que esperar hasta finales del siglo XVIII, al hilo del éxito de Antoine Galland o el trabajo de sir William Jones. Y no digamos ya en España, con las primeras versiones (indirectas, del Conde de Noroña y Valera) ya entrado el siglo XIX. Sorprende igualmente que entre las decenas de traducciones del árabe hechas en la Peninsula entre los siglos XII y XIII (incluidas las de la denominada Escuela de Traductores de Toledo) no tenemos constancia de ninguna obra de poesía. En alguna ocasión has mencionado a al-Yábiz y su teoría sobre la imposibilidad de la traducción de poesía. ¿Qué explicación le das a esto?

Seguramente al-Yáhiz, ${ }^{13}$ que está viendo las traducciones que se hacen de filosofía, de materia médica y científica, u otras similares, no hace más que constatar una realidad. Al-Yáhiz ya era bastante crítico sobre las traducciones técnicas al árabe, porque la lengua no alcanzaba el nivel lingüístico que él exigía para los autores árabes. Tampoco los árabes se interesan por la literatura griega o latina propiamente dicha, y no la traducen. Aunque se sabe de pasajes de la Odisea que han pasado a los libros de viajes árabes, no

I3 A este respecto, véase Vernet, Juan: La cultura hispanoárabe en Oriente y Occidente, Barcelona: Ariel, 1978 (especialmente capítulo 3), o también en Vernet, Juan: Lo que Europa debe al islam de España, Barcelona: El Acantilado, I999. consta que se tradujese. Si al-Yáhiz pidió que alguien le tradujese al árabe algún verso griego, seguramente lo encontraría horrible. Y sin duda habría sido peor si le hubiesen traducido al griego o siriaco algún poema árabe, él que disfrutaba tanto con la poesía. Y esa es la pauta que siguen los traductores del árabe al latín y al castellano en los siglos XII y XIII. La postura de al-Yáhiz también se da, pero a la inversa, en Italia. Gabrieli — que es una de las personas que más me han influido en el gusto por autores árabes- menciona el caso de Petrarca. Decía Petrarca que los árabes son nefastos para la poesía. Pero, claro, si le has pedido a un marinero que ponga en italiano un poema árabe, ¿qué va a salir? Son posturas rígidas que carecen de sentido. Porque, a pesar de todo, cada poema tiene una historia que va contando. Tienes que adaptarla; y ahí también entran las modas. Sasson Somekh escribió un artículo sobre un traductor árabe que traduce un poema de Shelley y lo hace en forma de casida. ${ }^{\mathrm{I}} \mathrm{Y}$ lo critica bastante. Pero es que había que traducirlo como poesía. Y si en árabe a finales del siglo XIX o principios del XX todavía no se ha inventado la «poesía libre», tienes que adecuarte a lo que se entiende por poesía. Las traducciones que hace Valera, convirtiendo los poemas árabes en romances o silvas, están muy bien para el modelo romántico del siglo XIX, pero traducir la elegía de $\mathrm{Abu}$ 1-Baqa al-Rundi en coplas manriqueñas es una tergiversación bastante grave, divertida quizá - y él lo explica con gracia-, pero grave. Era bastante lógico que para los Poemas arabigoandaluces a García Gómez no le gustase en absoluto ese modelo, ni convertirlos en romances.

${ }^{14}$ Somekh, Sasson, Genre and Language in Modern Arabic Literature, Wiesbaden: Otto Harrassowitz, I99I, «Chapter ro: Shelley in Neoclassical Arabic», pp. Io9-II7. El traductor árabe es Qusțandī Dāwūd, y su traducción se publicó en 1933, en la revista Apollo. 
Y tiene mucha razón porque el romance es tan español, y ¡es tan fácil hacer malos romances! Como en el caso de Valera, tienes la impresión 312 de que te están contando otra historia.

\section{Porque resulta un tanto impostado, ¿̇no?}

Posiblemente. Y sobre todo porque a veces es muy facilón, demasiado. Eso también explica que a mí no me guste la rima en traducción. Quizás porque soy heredera de la Generación del 27. También es verdad que me importa mucho lo que dice el texto. Y me parece que hay que prescindir lo menos posible de lo que dice. Ahí tenemos ya muchísimos problemas porque la lengua árabe es bastante concisa. Y sí, ellos pueden jugar con su lengua y hacer moaxajas con versos muy cortos.

En la base de datos de traducciones Taryamed, ${ }^{15}$ tu producción abarca siete traducciones de poesia andalusí, con selección, estudio y notas, y tres contribuciones como traductora en antologías. Empecemos por los Poemas de al-Rusafi (I980).

Al entrar en tercero en la especialidad de Semíticas, al primer profesor de árabe con el que me tropecé en clase de «Árabe III», y que resultó ser [Pedro Martínez] Montávez, le pedí que me dirigiera una tesina sobre poesía, y me sugirió que tradujese a Saadi Youssef. Empecé, y por eso mi primera traducción es un poema suyo publicado en la antología iraquí. ${ }^{6}$ Lo que pasa es que Montávez se trasladó a Sevilla. Además, tampo-

I5 $C f r$. www.taryamed.net, base de datos de acceso libre que recoge las obras traducidas del árabe y del hebreo hacia el castellano, el catalán, el gallego y el euskera - y viceversa-, publicadas desde 1959. Taryamed es resultado del proyecto I+D PPIIIo-0284- 366o de la Escuela de Traductores de Toledo (Universidad de Castilla-La Mancha).

I6 Literatura iraqui contemporánea, prólogo y nota preliminar de Pedro Martínez Montávez. Serie «Antologías nacionales», núm. I, Madrid: Instituto Hispano-Árabe de Cultura, 1977 . co estaba muy contenta porque no me acababa de gustar esa poesía moderna, siendo como era la época de la literatura de compromiso, la poesía social. Así que fui a don Emilio y le dije: «Don Emilio, quiero hacer una tesina de poesía árabe, traducir poesía de al-Ándalus». «Ah, muy bien - me dijo-; como recientemente ha sido editada la poesía de al-Rusafi, que además tiene un tamaño muy adecuado, son 62 poemas, póngase a ello... Pero que le dirija Granja». Y yo me puse a traducir. Granja a veces me dirigía y a veces no, porque nos faltaban horas. Al final, yo me había descuidado y me dijo: «Tiene que presentarla ahora. Tiene que hacerla ahora porque necesitamos profesores. Y si termina la tesina, la contratamos». La terminé. De aquellos días duros, aparte de estar obsesa completamente y no dormir, recuerdo que me ayudó Yusuf Salem, un compañero y buen amigo kuwaití, que luego hizo una tesis editando una parte de la Ihata fi ajbar Garnata. Mi hermana menor me pasaba a limpio las cosas que yo iba acabando. Fue mi primera crítica importante. Me decía: «Oye, que esto no se entiende... que aquí no entiendo nada». Y yo le contestaba: «Bueno, tú déjalo, que ya me lo dirá el tribunal». Aquello me hizo pensar en la importancia de que alguien que no sea de árabe lea lo que traduces, para que vea las cosas que nosotros no vemos, porque muchas veces, cuando no entendemos muy bien, hacemos traducciones defensivas, ponemos palabra por palabra, y no funciona bien.

\section{¿Cómo surgió la ocasión de publicar ese poemario?}

Cuando más adelante [Jesús] Munárriz andaba buscando publicar cosas de poesía hispanoárabe, Mercedes García-Arenal le dijo: "Quien tiene algo de eso es Teresa Garulo». Entonces ya revisé bastante la traducción. Supongo que algunas cosas deben de seguir estando un poco regular. Quizás incluso algo 
equivocado. Salió una reseña muy dura diciendo cosas que no eran verdad. Y Granja me preguntó: «Esto que dice este señor es cierto?». Y le respondí: «Unas veces sí, pero otras veces no, porque he usado una versión distinta, tomada de la edición, y no de las antologías. Pero hay alguna cosa que sí». Lo que pasa es que la edición quedó muy bien. Don Elías [Terés], cuando la vio, dijo: "Así es como hay que editar la poesía». Las publicaciones anteriores, ya fueran del Consejo [CSIC] o de otro organismo oficial, tenían el problema de que la gente no las compraba porque la distribución era muy mala. Ésta, sin embargo, tiene un diseño muy bonito. La introducción es la típica de una licenciada recién salida de la universidad, que todavía no sabe qué hacer con las fuentes árabes, porque espera de ellas lo que no suelen dar: datos biográficos. Digamos, en resumen, que de mis primeras traducciones ésa es la más importante, aunque también me publicaron poemas, y textos en prosa, en las otras dos antologías del Instituto Hispano-Árabe, la de literatura tunecina ${ }^{\mathrm{I} 7}$ y la de literatura y pensamiento marroquíes contemporáneos. ${ }^{18}$

Hoy, pasados 40 años desde esa primera traducción, ¿qué cualidades consideras indispensables en un/a traductor/a competente? ¿Basta una buena preparación técnica?

Que sepa escribir en español. Esa es la primera. Lo demás lo acabará aprendiendo - porque se supone que seguirá estudiando y

17 Literatura tunecina contemporánea, prólogo de Ya far Mayid y nota preliminar de Carmen Ruiz y Fernando de Ágreda, Serie «Antologías nacionales», núm. 2, Madrid: Instituto Hispano-Árabe de Cultura, 1978.

I8 Literatura y pensamiento marroquies contemporáneos, introducción de Abderrahman Cherif-Chergui; nota preliminar de Fernando de Ágreda, Serie «Antologías nacionales», núm. 3, Madrid: Instituto Hispano-Árabe de Cultura, I98I. leyendo árabe- Mucha gente, y lo digo por mis alumnos, piensa que escribir bien es escribir de una forma poco natural y retorcida, y hacer frases muy largas. Creo que, aunque el autor escriba frases muy largas, tienes que poner orden. Eso lo aprendí precisamente no con el Libro del brocado, pero sí con el prólogo de ese libro. Claudio Guillén me dijo: «Estás haciendo unas frases muy largas y resulta más difícil de entender. ¡Pon más puntos!». Al principio nos pasa a todos cuando somos jóvenes, que somos muy vanidosos, y creemos que lo hacemos todo bien. Pero es verdad, hay que escribir frases más breves. No tanto como Azorín, que a mí de pequeña no me gustaba nada por eso. $\mathrm{Ni}$ tampoco debe importarte repetir para retomar el hilo porque, si no, te pierdes. En el caso del árabe, en los prólogos no importa que digas dos veces seguidas el nombre del autor. A la gente que no conoce estos nombres siempre le parecen demasiado exóticos. Si se los repites, a lo mejor alguno se le queda. No es tan grave repetir.

Te acabas de referir al Libro del brocado, un libro maravilloso sobre el refinamiento en la corte abbasi del siglo IX, que publica Alfaguara en I9go en la colección que dirigía Claudio Guillén. De algún modo, es un oasis en tu producción.

No, nada de oasis, si lo piensas bien; tiene más de quinientos poemas.

Es cierto. Yo estaba pensando en su origen oriental, frente al resto de tu producción, andalusí.

Claudio Guillén tenía el proyecto de hacer una colección de Clásicos en Alfaguara. Se hicieron bastantes, pero el proyecto acabó malográndose. Nos convocó un día a muchos arabistas. Posiblemente gracias también a Mercedes García-Arenal, que lo puso en contacto con nosotros. El único libro que acabó cuajando 
fue el mío. En parte porque tuve más paciencia. En esa lista estaba también el Libro de los avaros, que luego publicaron en Editora Nacional. ${ }^{19} \mathrm{La}$ 314 idea inicial del Libro de brocado fue de García Gómez, lo había comentado en clase: «Las obras árabes son tan largas que no hay forma de hacer una tesis con ellas, pero el Libro del brocado tiene un tamaño muy adecuado...». Acto seguido fui a decirle a Granja que querría que ese fuera mi tema de tesis. Pero me dijo que la estaban haciendo en Francia, y en esa época la idea de repetir el trabajo de alguien les parecía imposible. «Eso no se hace. Hay material de sobra», me contestó.

\section{¿Ya estaba hecha la edición crítica?}

Sí, desde I886, preparada por Rudolph E. Brünnow. Pero la tesis de M. F. Ghazi prometía ser un estudio crítico del autor, la obra, el género, etc. Seguí con mis clases - ya era profesora-, mientras esperábamos que se nos ocurriera algún tema relacionado con la poesía. Y haciendo los cursos de Doctorado. En la clase de «Dialectología árabe», que nos daba don Elías Terés - una parte importante del curso estaba destinada al dialecto árabe de al-Ándalus-, supe de los trabajos de geografía lingüística en países árabes, y despertó de tal modo mi interés que, en cuanto pude, en Doctorado, me matriculé en la asignatura de "Geografía lingüística» que impartía don Manuel Alvar. Fue él quien me sugirió hacer la tesis sobre los arabismos en el léxico andaluz. Aprendí mucho, y disfruté mucho haciéndola. Pero también sufría mucho, porque, cuando acabas de salir de la Facultad, tienes muchas inseguridades, y no sabes si lo estás haciendo bien o no; era una disciplina

I9 Al-Ŷāhiz: Libro de los avaros, traducción, introducción, notas e índices Serafín Fanjul, con la participación de Alcaén Sánchez. Madrid: Editora Nacional, ı984. bastante nueva para mí. La leíio en 1978 . Una vez terminada, empecé con la traducción de $E l$ libro del brocado. Fue entonces cuando conocí a Claudio Guillén. La terminé creo que alrededor de 1985, pero hubo una especie de crisis en Alfaguara, después de entregarla yo, y todo se quedó en el aire. La rescataron varios años más tarde. Estaban al frente Luis Suñén y Manuel Rodríguez Rivero. Me llamaron y me dijeron: «Tenemos tu traducción, vamos a ver si la sacamos ahora». Se publicó ${ }^{21}$ por fin en 1990.

La edición es bonita y el estudio es magnifico. ¿Q Qué acogida tuvo el libro?

Para mi gran desesperación, cuando salió el libro nadie le hizo caso. Ni siquiera lo mandaron a los periódicos para que hicieran una pequeña reseña. Munárriz se encargaba de mandar las obras a Pueblo, a Informaciones - un periódico de la tarde-, a El País, pero estos nada. Lo dejaron morir. Una vez entré en la librería del Grupo Santillana en Juan Bravo y, dando una vuelta por el departamento de labores - porque a mí me gusta hacer punto- allí me lo encontré. Y otra vez encontré una reseña de él en Nuevo estilo, que es una revista sobre muebles y decoración que yo usaba de vez en cuando. Una reseña que hacía una pobre señora pensando que iba a ser un libro sobre tejidos. Escribí una carta bastante indignada a los de Alfaguara. Aquel mismo año Alfonso Ussía había publicado su Tratado de las buenas maneras, dedicado

20 Garulo Muñoz, Teresa: Arabismos en el dialecto andaluz. Tesis dirigida por Manuel Alvar López. Universidad Complutense de Madrid, I978. Parte de este trabajo fue publicado en Garulo Muñoz, Teresa: Los arabismos en el léxico andaluz (según los datos del Atlas Lingüistico y Etnográfico de Andalucia, Colección de Estudios Cordobeses, 29, Madrid: Instituto Hispano-Árabe de Cultura, I983.

${ }_{21}$ Al-Waššā': El libro del brocado, traducción, estudio e índices de Teresa Garulo, Madrid: Ediciones Alfaguara, I990. 
a la reina, acababa de empezar la I Guerra del Golfo... ¿No podían haber hecho propaganda de un libro sobre la vida y los códigos de buena educación en Bagdad en el siglo IX? Les escribí una carta muy enfadada. Amaya Elezcano me dijo: «Sí, sí, tienes toda la razón». Lo volvieron a sacar, ${ }^{22}$ con el subtítulo «Bagdad en el siglo IX», pero tampoco. $\mathrm{Y}$ al final destruyeron los ejemplares que quedaban. Hace alrededor de un año — quizás porque la vida tiene curiosos renaceres - vino a hacerme una entrevista precisamente sobre el Libro del brocado un joven periodista llamado César, no recuerdo su apellido, de un periódico de Castilla y León. Y los ejemplares del pobrecito libro, destruidos. Como está hecho antes de internet, no tengo ni PDF. La verdad es que me sigue pareciendo un libro interesante por toda clase de razones, y que te da una gran cantidad de información que está muy bien.

Con mucha influencia en Occidente y en Oriente. Imprescindible para traducir a autores como Abu Nurwás, sin ir más lejos. Y con mucha información, como tú dices, sobre el hablar y el amar, el vestir y el comer. ${ }^{23}$

Sí, además, en contra de lo que se dice, no hay dos libros de adab iguales. Alguien me dijo que ese libro era igual que una obra de Ibn Qutayba. Las comparé y había cinco anécdotas coincidentes. Todos van superándose, no en el sentido de ser mejor que el anterior, sino que van más allá, con historias distintas, con preocupaciones diferentes, y a menudo inclinándose más a lo místico. Que ya entonces para muchos

22 Al-Waššā': El libro del brocado: la elegancia en Bagdad en el siglo IX, traducción, estudio e índices de Teresa Garulo, Madrid: Ediciones Alfaguara, 200I.

${ }_{23}$ Garulo, Teresa: «Comer barro (Nota al capítulo Xxx del Kitāb al-muwaššà de al-Waššă)». Al-Qantara: Revista de estudios árabes, vol. 8, fasc. I-2, I987, pp. I53-I64. elegantes era señal de refinamiento ponerse un poco místico.

$Y$ desde el punto de vista de la traducción, un texto difícil, plagado de citas, en prosa rimada, con decenas de términos técnicos (objetos, vestidos, alimentos), de términos abstractos y polisémicos como muruwwa o adab, que explicas en la introducción.

Eso es verdaderamente terrible. Ahí cuento cómo leyendo la literatura clásica del siglo XVI y XVII hallaba equivalencias que me parecían válidas, cómo adab podía ser traducido por «cortesía» en el modelo medieval...

\section{En alguna medida, Gracián...}

Sobre todo Gracián. Me ayudaba con términos como «magnánimo», «longanimidad», «discreto», cosas que ahora prácticamente no nos dicen nada y no sabemos muy bien qué significan.

${ }_{\grave{\zeta}}$ Crees que se han incorporado a la bibliografía española las obras fundamentales de la poesía árabe clásica? ¿Q Qué podemos hacer para que en los centros de enseñanza se conozca a Ibn Hazm o Ibn Shubayd, a Averroes, a Ibn Arabi o a Abentofail, a Ben Quzman?

Creo que eso tiene que ver más con el modelo educativo. En el bachillerato todos sabíamos de Abentofail. Quizá tenga que ver con que hice el bachillerato en Andalucía, en Baza, y él era de cerca de Guadix. Lo teníamos más en cuenta. El filósofo autodidacto lo había leído hacía siglos, pero hace dos años tuve que escribir un capítulo de literatura de al-Ándalus para Routledge. Lo volví a leer y me quedé absolutamente deslumbrada por la capacidad de estos andalusíes para articular tan bien un pensamiento y llegar con tanto rigor a conclusiones transcendentes, y siempre de una manera tan amena. No es exactamente una novela, que eso sería una 
transposición demasiado anacrónica, pero te va llevando de un modo... Debí de haberlo leído en el bachillerato porque en casa estaba. Mi madre pensaba que los poetas árabes y hebreos de alÁndalus eran nuestros. Ahí estaban los Poemas arabigoandaluces y diversos estudios sobre poetas hebreos: Ibn Gabirol, Yehudá Halevi.

Hablando de ediciones, hay algo que no querría pasar por alto. El 9o\% de tus traducciones están en la colección "Poesía» de Ediciones Hiperión, una casa madrileña, comercial y con un catálogo de poesía más que sólido. Cuando publicas los Poemas de al-Rusafi en I980, en esa colección habia una traducción del árabe (del palestino Tawfiq Zayyad, hecha por María Rosa de Madariaga ${ }^{24}$, $y$ encontrar traducciones del árabe en editoriales no académicas era algo excepcional.

El primer contacto fue a través de Mercedes García-Arenal, lo recuerdo. Jesús Munárriz le dijo que quería publicar poesía árabe, y Mercedes le contestó que para esas cosas hablara con Teresa Garulo. Entonces me escribió y quedamos. Debía de colaborar todavía con los de Visor — creo que empezaron juntos en Endymión-, porque nos vimos en la librería de Visor que había en Moncloa. No me acuerdo de cómo se llamaba el director de Visor...

\section{¿Chus Visor?}

Debe de ser. A él le mandé mucho más adelante el proyecto de una antología de poesía de al-Ándalus. Aunque he tenido algún contacto con él, he tratado más con su mujer, que estaba en la librería de la Facultad. Me dijo que aceptaban la antología como yo quisiera plantearla, pero es que con las clases no tengo tiempo para pararme a pensar. Tengo algunas cosas que están

${ }^{24}$ Zayyad, Tawfiq: Ammán en septiembre y otros poemas. Traducción, introducción y notas de María Rosa de Madariaga. Madrid: Hiperión, I979. terminadas, pero soy un poco indecisa, a la hora de escoger qué se puede eliminar. Tengo una antología de Yamil, ${ }^{25}$ que preparé cuando fui a Estados Unidos. Estaba terminada, pero tengo que escoger, quitar. La mayoría de los diwanes son demasiado largos. Lo mismo que Ben Sahl, que también lo había traducido entero. Cuando Munárriz lo vio, dijo: «jTodo esto?» Entonces dije: «Ah, haré una selección».

\section{Munárriz pertenece a esa pléyade de editores} - cada día más reducida - que se esfuerzan por garantizar la calidad de las traducciones. ¿Cuál ha sido tu experiencia con él, sabiendo que además es traductor y poeta?

La relación ha sido siempre de libertad absoluta. Nunca ha puesto ninguna pega. Cuando en la edición de Ben Sahl descubrí que me había saltado una estrofa de una moaxaja, que es algo que puede pasar, me dejó rehacerla... Me ha dejado siempre manga ancha. Me ha dado las pruebas con tiempo, y ha dado por bueno lo que yo hacía, que no sé si es porque qué iba a decir de árabe. En el caso de Ibn Sara y en alguna otra, ya monté yo al ordenador el texto árabe del libro y le expliqué cómo lo había hecho para facilitar la compaginación. Como te digo, la relación con Munárriz ha sido siempre muy buena. Desde el punto de vista contractual, excelente. Y se han vendido bastante bien. De hecho, de al-Rusafi hay dos ediciones. ${ }^{26}$ Ben $\mathrm{Sahl}^{27}$ tiene tres, Las poetisas, ${ }^{28}$ dos... Ahora

25 Garulo, Teresa: «En torno a un poema de Ŷamīl al'Udrī ». Al-Qantara: Revista de estudios árabes, vol. I9, fasc. I, I998, pp. II5-I30.

26 Ar-Rușāfì de Valencia: Poemas, traducción e introducción de Teresa Garulo, Madrid: Hiperión, 1986.

${ }_{27}$ Ben Sahl de Sevilla: Poemas, selección, traducción e introducción de Teresa Garulo, Madrid: Hiperión, 1983, I984.

${ }_{28}$ Garulo, Teresa: Dìwān de las poetisas de al-Andalus, Madrid: Hiperión, I986, 1998. 
están un poco muertas las pobres poetisas. Me dijo una alumna que había intentado comprarla y que la había encontrado en internet y que la vendían de segunda mano por i6o euros. Han funcionado muy bien. Sobre todo la de Ben Sahl, que gustó mucho y en un año se agotó. Y enseguida hicieron una segunda edición. Es verdad que eran tiradas cortas.

\section{¿Te consta que salieran reseñas?}

Sí, hubo reseñas en periódicos. Alguna de Luis Antonio de Villena (en Pueblo, en El País) y quizás de algún otro poeta. Alguna apareció en el antecedente de la Guía del ocio o en una fase previa de esa guía. Yo me ponía muy contenta y guardo los recortes. También en revistas de nuestra especialidad, pero salen mucho más tarde.

Antes has mencionado al recién elegido presidente de la sección Traductores de la Asociación Colegial de Escritores ACETT, de la que eres uno de los miembros más antiguos. Dos de sus objetivos son dar a conocer el papel del traductor y mejorar su estatus. ¿Crees que el ciudadano de a pie y nuestras instituciones son conscientes del papel que juegan los traductores? ¿Qué te parece lo más urgente en este sentido?

Tengo la impresión de que las instituciones, en general, no ven el papel que cumple el traductor. Hubo una época en que la política ministerial sí se ocupaba de él, dando becas para algún proyecto de traducción, ${ }^{29}$ pero dejó de hacerlo. En cuanto a las asociaciones, mi

29 Para la recopilación, edición, traducción y estudio de los Poemas del fuego y otras casidas, de Ibn Șāra AšŠantarīnī, recibió una ayuda a la creación literaria (modalidad de traducción) del Ministerio de Cultura en i996. La obra fue publicada en Ediciones Hiperión en 200I. Estas ayudas a la traducción de lenguas extranjeras fueron eliminadas durante el segundo gobierno de José María Aznar y no han vuelto a ser convocadas. marido, José Luis López Muñoz ${ }^{\circ}$ es traductor, y cuando volvió de Estados Unidos, donde era profesor, fue a inscribirse en APETI, la asociación anterior a ACETT, y se hizo muy amigo de Esther Benítez. Esther era una mujer con muchísimo empuje y con una capacidad inmensa para movilizar a la gente. Insistía en que había que estar en las asociaciones, porque el número de miembros importa. Él entonces se hizo miembro de ACETT y yo también me inscribí. Yo tenía ya tres o cuatro libros publicados. De hecho, a propósito de la publicación de los Poemas de Ben Sahl, Esther Benítez me hizo una entrevista en televisión para el programa República de las Letras. Y en CEDro también debo de ser de las primeras traductoras de árabe que se apuntó.

¿Crees que ha mejorado el mercado del libro traducido del árabe?

Creo que sí, hay más editoriales que publican obras árabes. Pero, por otra parte, piensa que el Instituto Hispano-Árabe dejó de publicar libros, que nadie lo ha sustituido. E1 Instituto Egipcio también publicaba ediciones y traducciones, y ya no lo hace. La Universidad, tampoco ha hecho nada nunca. El Consejo, algo más. Luego alguien decidió que las traducciones no valían para hacer una tesis. Ahora parece que están revalorizándolas, en parte porque los anglosajones han decidido hacerlo. Recuerdo que vino a Tarazona un traductor del Quijote al

3o José Luis López Muñoz (Madrid, I934) es licenciado en Medicina y en Filología Inglesa por la Universidad Complutense, y doctor en Filosofía Escolástica en Roma. Ha traducido del inglés a Henry James, Jane Austen, Virginia Woolf, John Dos Passos, E. M. Forster, William Faulkner, F. Scott Fitzgerald, Rudyard Kipling y Patricia Highsmith, entre otros. En I980 recibió el «Premio Nacional de Traducción» por su versión de la novela Joseph Andrews, de Henry Fielding, y en 2000, el «Premio Nacional a la Obra de un Traductor». 
inglés y nos contó que, cuando dijo en su universidad que quería traducir, le dijeron: «Pues olvídate de una carrera académica». Tengo la impresión de que son los anglosajones los que están haciendo que cambien las cosas. Al menos en nuestra especialidad.

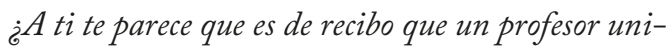
versitario publique una treintena de traducciones $y$ las agencias de evaluación de la calidad no computen ni una sola como mérito académico?

Me parece un poco absurdo, porque para todos los profesores -en particular los que me precedieron durante diez años y los que me siguieron durante otros cinco o seis - la base de nuestros trabajos era un original que estudias, analizas, editas y traduces, dando lugar a muchísimos artículos de investigación. Eso es bastante lógico. ¿Cómo vas a conocer esa literatura, cómo vamos a saber qué dijo Abentofail si no es a partir de traducciones?

¿Y quién va a cumplir esa tarea sino los arabistas?

En las encuestas que ACETT ha hecho para el Libro Blanco de la traducción, las dos veces tuve que avisar: «Pero es que no soy exactamente una traductora profesional; soy profesora $y$ traduzco». Y en parte todos los arabistas hemos sido así. Arabistas que vivan de traducir libros creo que no hay. Todos tienen un puesto en la universidad - la mayoría-, o en un instituto, o son traductores de organismos internacionales, o intérpretes. En cualquier caso, el mercado del libro árabe es realmente pequeño. $\mathrm{Y}$ eso que ha mejorado mucho. Porque esa bibliografía ${ }^{3 \mathrm{I}}$ que hice antes del año 88 es cortita, a pesar de ser exhaustiva. Ahora bien, cuando en r988 le dan

$3^{\text {I }}$ Garulo, Teresa: Bibliografía provisional de obras árabes traducidas al español (1800-1987). Cuadernos Bibliográficos de la Biblioteca Islámica Félix M. ${ }^{a}$ Pareja, II, Madrid: ICMA, 1988. el Premio Nobel a Mahfuz, la producción de traducciones se dispara, y además es imparable. La cuestión es que sigue siendo un mercado muy restringido. Aquí no pasa como en Francia, que tienen tanta curiosidad por sus antiguas colonias. Estará mal decirlo pero es cierto.

En Francia, la poesía de Abu Nuwás lleva vendidos más de I3.00o ejemplares, y El edificio Yacobián más de 30.00o. ¿Quién es responsable? ¿Las editoriales?

Un poco sí. También debe de ser que en España la gente no lee, o lee muy poco. Se edita muchísimo, pero son tiradas muy pequeñas y el índice de lectores es muy bajo. Más de la mitad de la población no lee ningún libro al año. En esto la poesía tiene más éxito, porque los lectores de poesía son unos lectores incondicionales, que leen todo lo que sea poesía. No lo digo en sentido negativo, sino al contrario, son lectores que están buscando poesía todo el tiempo.

¿Qué trabajos te ocupan ahora?

Ahora estoy muy dispersa, porque las clases me quitan muchísimo tiempo. He terminado algunos trabajos de investigación, que saldrán a su debido tiempo porque acabo de entregarlos. Son cosas para el escaparate universal, es decir, en inglés. Lo último es un repaso a las moaxajas egipcias y sirias, que he traducido. Al ser en inglés, no me ha importado traducir más literalmente; en español habría intentado darles forma de poema estrófico y eso habría dificultado la tarea.

\section{¿Qué te gustaría haber traducido?}

Autores en prosa hay algunos como Ibn alYawzi... Hace un tiempo mandé a Siruela una muestra de unas cuantas anécdotas de su libro Kitab al-ziraf. Como son historias cortas, pensé: así la gente no se cansa... Me encanta esa narra- 
tiva que no estaba hecha con fines literarios. Por ejemplo, las obras de al-Tanuji. Ahí te repito lo de la influencia de Gabrieli. Me parece maravilloso todo lo que cuenta al-Tanuji, en Al-Faray ba'd al-shidda, ${ }^{32}$ Nishwar al-mubadara y otros.

\section{Al-Tanuji... ¿̇es un autor al que traducirías hoy?}

Por supuesto. Pero, claro, son cinco tomos. Como decía García Gómez, son demasiado largos, eso no hay quien lo publique. Y lo mismo diría de Al-Iqd al-farid de Ibn Abd Rabbihi. ${ }^{33}$ $\mathrm{Al}$ inglés lo han traducido porque hay alguna institución árabe con montañas de dinero que ha pagado bien, porque son horas y horas de trabajo. ${ }^{34} \mathrm{O}$, ¿quién va a traducir la Dajira? Son libros que uno solo no puede hacer, o tiene que suspender absolutamente todo lo demás. Hay otros libros también deliciosos, imposibles, como por ejemplo Qala'id al-iqyan. Lo que ocurre con estos dos libros es que no los tratamos como antologías, sino como libros para extraer biografías de poetas. $35 \mathrm{Y}$ ellos no pretendieron hacer biografías. Nos decepcionan siempre porque, aparte de que es difícil y no entiendes bien, o casi nada, tienes el problema de que no te están contando lo que quieres que te den,

32 Garulo, Teresa: «Erudición y nostalgia. Al-Hanīn ilà 1-awțān en el editor de al-Faraŷ ba 'd al-šidda de al-Tanūjī». Al-Qantara: revista de estudios árabes, vol. 33, fasc. I, 20I2, pp. IO7-I46

33 Veglison, Josefina: El collar único de Ibn Abd Rabbibi, Madrid: Síntesis, 2006.

34 Ibn 'Abd Rabbih: The Unique Necklace: Al-'Iqd al-Farid, trans. by Issa J. Boullata, Great Books of Islamic Civilization, 3 vols. Reading: Garnet, 2006-20Ir. En esta edición financiada por el «Center for Muslim Contribution to Civilization Muhammad b. Hamad A1-Thani» de Qatar, participaron junto a Issa Boullata, Roger Allen y Terry De Young, entre otros. Hace apenas un mes falleció, muy anciano, el profesor Boullata, titán y maestro de traductores. Desde aquí, nuestro afectuoso recuerdo y admiración.

35 Véase, Garulo, Teresa: «Biografías de poetas». En María Luisa Ávila (coord.): Biografías y género biográfico en el Occidente islámico. Madrid: CSIC, I997, pp. II7-I26. unos datos para hacer una biografía e incluirla en un estudio.

Me estoy preguntando cómo voy a transcribir esos titulos. ${ }^{36}$

Sobre eso hay una cosa de la que me convenció Granja y creo que sigue teniendo razón. Él decía que los que van a leer estas cosas que hacemos no saben árabe y les da igual cómo esté escrito. Así es que lo más cómodo, lo mejor, es hacer la transcripción en serio, porque alguien la entenderá, y a los demás les va a dar igual que tenga más signos diacríticos o no los tenga en absoluto. Se los van saltar, tanto si los pones como si no... A mí me gusta poner las rayitas y los puntos. En la única cosa que decidí alejarme de la escuela de la revista $A l-A n d a l u s$ es con el artículo. Cuando le oí a Munárriz decir «AlRusafi», dije: «Al-Rusafi, no: Ar-Rusafi». Es una convención y me parece bien porque si no transcribes lo más parecido a la transcripción científica, no reconoces el nombre árabe. Estos días llegó a la lista de distribución de ACETT el nombre de una autora omaní llamada Jokha Alharthi, 37 cuya novela ha ganado un premio de traducción. Me habría gustado que la revista BANIPAL, donde aparecía, hubiera incluido su transcripción científica para poder identificar su nombre en árabe. Estamos de acuerdo en que es así como figura en su pasaporte, pero creo que debería ofrecerse también la convención científica.

\section{Pero es que hay tantas convenciones...}

Bueno, pero qué me dices de las absurdas

${ }^{6}$ Siguiendo los criterios de edición de Trans, he descartado el uso de signos diacríticos para la transliteración de nombres y títulos árabes en el cuerpo del texto.

37 Jokha Alharthi (Ŷ̄üja al-Hāritīi): Celestial Bodies (Sayyidāt al-qamar), novela traducida del árabe al inglés por Marilyn Booth y ganadora del «Man Booker International Prize» 2019. 
simplificaciones que hacen los de la Agencia EFE. El pobre Abdelfattah Sisi, que sea Abdelfatá. Me parece casi blasfemo. Abdelfatá, siervo del eunuco, en lugar del siervo de Dios. Es una hache que en árabe se pronuncia. Y lo mismo ocurre con Ammán, no Amán; no cuesta tanto mantener la doble consonante.

Teresa, si lo dejamos aqui, llegas a tiempo a tu tren.

Sí, yo también creo que es suficiente. ¿He dado mucha doctrina...? (Risas)

Solo me queda agradecerte tu tiempo y tu enorme amabilidad.

RECIBIDO EN JUNIO DE 2019

ACEPTADO EN JUNIO DE 2019 VERSIÓN FINAL DE JUNIO DE $20 I 9$

\section{REFERENCIAS BIBLIOGRÁFICAS}

Almarthi, Jokha (20I8): Celestial Bodies, translated by Marilyn Booth, Dingwall: Sandstone Press.

Antología de la poesía andalusi (2007), edición, selección y estudio de Manuel Francisco Reina; traducciones de Teresa Garulo, Miguel José Hagerty y Muhsin al-Ramli, Madrid: Edaf.

Arias Torres, Juan Pablo, Manuel C. Feria García y Salvador Peña Martín (2003): Arabismo y traducción. Entrevistas con J.M. Fórneas. J. Cortés, M. Cruz Hernández, J. Vernet, L. Martinez, P. Martinez Montávez, M.L. Serrano, Madrid: CSIC.

Asín Palacios, Miguel (1942): Crestomatía del árabe literal con glosario y elementos de gramática, Madrid: Instituto Arias Montano.

Ben Sahl de Sevilla (1983): Poemas, selección, traducción e introducción de Teresa Garulo, Madrid: Hiperión.

García Gómez, Emilio (1944): Antología Árabe para principiantes. Textos árabes sin vocalizar seleccionados y reeditados con un glosario, Madrid: Espasa-Calpe.

García Gómez, Emilio (I997): «Discurso de investidura con el grado de Doctor honoris causa por la Universidad de Granada», en Elegía Andaluza. (Homenaje a D. Emilio García Gómez), Sevilla: Asociación Andaluza de Profesores de Español Elio Antonio de Nebrija.

Garulo, Teresa (1972): Poemas de Al-Rusafi. Tesis de licenciatura dirigida por Fernando de la Granja. Universidad Complutense de Madrid.

Garulo, Teresa (1978): Arabismos en el dialecto andaluz. Tesis doctoral dirigida por Manuel Alvar López. Universidad Complutense de Madrid.

Garulo, Teresa (1983): Los arabismos en el léxico andaluz (según los datos del "Atlas Lingüistico y Etnográfico de Andalucia»), Madrid-Córdoba, Instituto Hispano-Árabe de Cultura/Diputación Provincial de Córdoba.

Garulo, Teresa (1986): Dìwān de las poetisas de AlAndalus, Madrid: Hiperión.

Garulo, Teresa (I987): «Comer barro (Nota al capítulo xxx del Kitab al-muwaššà de al-Waššā')», AlQantara: Revista de estudios árabes, 8.I-2, I53-I64.

Garulo, Teresa (I988): Bibliografía provisional de obras árabes traducidas al español (I80o-1987), Cuadernos Bibliográficos de la Biblioteca Islámica Félix $M^{a}$ Pareja, II, Madrid: ICMA.

Garulo, Teresa (I988): «Las traducciones del árabe al español desde i80o», Awraq: Revista de estudios sobre el mundo árabe e islámico contemporáneo, 9, I6I-I68.

Garulo, Teresa (I997): «Biografías de poetas», en María Luisa Ávila (coord.), Biografías y género biográfico en el Occidente islámico, Madrid: CSIC, II7-I26.

Garulo, Teresa (1998): «En torno a un poema de Ŷamī al- 'Udrī», Al-Qantara: Revista de estudios árabes, I9.I, II5-I3O.

Garulo, Teresa (1998): La literatura árabe de alÁndalus durante el siglo XI, Madrid: Hiperión.

Garulo, Teresa (1998-99): «Sobre la traducción de la poesía de al-Ándalus», Vasos comunicantes: Revista de ACE traductores, 12, 30-4I.

Garulo, Teresa (2009): «Las mil y una noches», en Francisco Lafarga y Luis Pegenaute (coords.), Diccionario histórico de la traducción en España, Madrid: Gredos, 786-789.

Garulo, Teresa (20I2): «Erudición y nostalgia. Al-Hanīn ilà l-awțān en el editor de al-Faraŷ ba 'd al-šidda de al-Tanūjī», Al-Qantara: Revista de estudios árabes, 33.I, I07-I46. 
Garulo, Teresa (2018): «Poesía árabe clásica y traducción», Vasos comunicantes: Revista de ACE traductores, 48-49, 9I-99.

Al-Hị̂nițī, Ŷūja (20IO): Sayyidāt al-qamar, Bayrūt: Dār al-Ādāb.

Iвм 'Авр Rаввін (2006-іп): The Unique Necklace: Al- 'Iqd al-Farid, trans. by Issa J. Boullata, Great Books of Islamic Civilization, Reading: Garnet.

Ibn RabĀH de Calatrava, Abū Tammām (2008): El cálamo del poeta, edición bilingüe, traducción y estudio de Teresa Garulo, Madrid: Hiperión.

Literatura iraquí contemporánea (I977), prólogo y nota preliminar de Pedro Martínez Montávez, Serie «Antologías nacionales», núm. I, Madrid: Instituto Hispano-Árabe de Cultura.

Literatura tunecina contemporánea (I978), prólogo de Ya far Mayid y nota preliminar de Carmen Ruiz y Fernando de Ágreda, Serie «Antologías nacionales», núm. 2, Madrid: Instituto Hispano-Árabe de Cultura.

Literatura y pensamiento marroquies contemporáneos (I98I), introducción de Abderrahmān CherifChergui; nota preliminar de Fernando de Ágreda, Serie "Antologías nacionales», núm. 3, Madrid: Instituto Hispano-Árabe de Cultura.

Locus amoenus. Antología de la lírica medieval de la Peninsula Ibérica (latín, árabe, hebreo, mozárabe, provenzal, galaico-portugués, castellano y catalán) [2009], edición de Carlos Alvar y Jenaro Talens, Galaxia Gutenberg-Círculo de Lectores.

Mahfuz, Naguib: Cuentos ciertos e inciertos, traducción de Marcelino Villegas y María Jesús Viguera, Madrid: Instituto Hispano-Árabe de Cultura, I974.
Ar-Rușāpī de VAlencia (ig86): Poemas, traducción e introducción de Teresa Garulo, Madrid: Hiperión.

Santiago Simón, Emilio de; Teresa Garulo y Joan Llopis: Espai i simbol en la poesia islàmica. Barcelona: Editorial Claret, 1998.

Aš-Šantarīnī, Ibn Șāra (200I): Poemas del fuego y otras casidas, recopilación, edición, traducción y estudio de Teresa Garulo, Madrid: Hiperión.

VEglison, Josefina (2006): El collar único de Ibn Abd Rabbibi, Madrid: Síntesis, 2006.

Viguera Molins, María Jesús (2003): «En homenaje a la profesora Rafaela Castrillo Márquez», Anaquel de Estudios Árabes, I4, 309-312.

Someкн, Sasson (1991): Genre and Language in Modern Arabic Literature, Wiesbaden: Otto Harrassowitz, "Chapter Io: Shelley in Neoclassical Arabic», I09-II7.

AL-Ŷ̄Ạız (I984): Libro de los avaros, traducción, introducción, notas e índices Serafín Fanjul, con la participación de Alcaén Sánchez. Madrid: Editora Nacional.

AL-WAššĀ' (I990): El libro del brocado, traducción, estudio e índices de Teresa Garulo, Madrid: Ediciones Alfaguara.

AL-WAššĀ' (200I): El libro del brocado: la elegancia en Bagdad en el siglo $I X$, traducción, estudio e índices de Teresa Garulo, Madrid: Ediciones Alfaguara, 200I.

Zayyad, Tawfiq (I979): Ammán en septiembre y otros poemas, traducción, introducción y notas de María Rosa de Madariaga, Madrid: Hiperión. 